\section{Immediate Desensitization in Teeth Affected by Amelogenesis Imperfecta}

Rudá França Moreira1, Rossana Gomes Figueiredo¹, Henrique Eduardo Oliveira ${ }^{2}$, Ana Christina Lamosa da Fonseca' ${ }^{1}$, Mauro Sayão de Miranda ${ }^{1}$

The aim of this paper was to describe a clinical case of immediate dental desensitization using a self-etch adhesive system in an adolescent patient diagnosed with amelogenesis imperfecta (Al). Al was associated with severe tooth sensitivity, treated by the application of a universal adhesive system for desensitization of the teeth affected by Al. Reduction of tooth sensitivity was assessed using a visual analog scale during all reevaluations. The technique was effective for reducing tooth sensitivity. It was concluded that the adhesive system for tooth desensitization had an immediate effect and maintained its effectiveness during a 12-month follow-up period.
'UERJ - Universidade do Estado do Rio de Janeiro, Rio de Janeiro, RJ, Brazil 2UFF - Universidade Federal Fluminense, Rio de Janeiro, RJ, Brazil

Correspondence: Dr. Rudá França Moreira, Rua Ana Leonídia, 343, Bl. B, apto 705. Engenho de Dentro, 20730-390 Rio de Janeiro, RJ, Brasil. Tel: +55-21-99347-8525. e-mail: rudamoreira@hotmail.com

Key Words: amelogenesis imperfecta, dental materials, dental enamel, dental clinics, dental enamel hypoplasia.

\section{Introduction}

Amelogenesis imperfecta (AI) is a hereditary anomaly of the enamel, which affects both dentitions and may cause tooth sensitivity, loss of vertical dimension, enamel deficiencies, pulp calcification, failed tooth eruption, impaction of permanent teeth and aesthetic commitment $(1,2)$. Enamel synthesis or amelogenesis occurs by the activity of ameloblasts after dentin formation (3). Historically, Al has been known and studied since 1890, but only in 1938 it was classified separately from dentinogenesis imperfecta and considered to possibly affect both deciduous and permanent teeth $(4,5)$.

Al can be classified according to phenotype and clinical aspect as follows: Type I or hypoplastic, involves problems in enamel secretion; Type II or hypomature, related to enamel maturation; Type III or hypocalcified, involves mineralization and Type IV, hypoplastic, hypomature and taurodontic (6). These teeth present different levels of color alteration, presenting dark brown color, increase of roughness and susceptibility to attrition, which results in the reduction of vertical dimension $(4,5,7)$.

Oral hygiene is often unsatisfactory owing to the irregularity of the tooth surface and sensitivity, contributing to a greater susceptibility to staining (8). According to the literature, the main sequelae in these patients, regardless of Al classification, are intense tooth sensitivity, poor aesthetics, risk of dental caries and decreased vertical dimension $(9,10)$. Thereby, different treatment strategies are available, according to the degree of damage, including the use of all types of glass ionomer cements, stainless steel crowns, amalgam restorations, adhesive restorations, metaloceramic crown, prefabricated resin veneer and multiple extractions requiring an overdenture $(7,11-14)$. This paper reports a case of a simple and useful protocol for immediate reduction of tooth sensitivity in a young patient with $\mathrm{Al}$ by using a self-etch adhesive system.

\section{Case Report}

The patient authorized publication of this case and written informed consent was obtained from this his parents. A male, aged 11 years, sought dental care at the Clinic of Adolescent Oral Health discipline at UERJ accompanied by his family. The main complaint reported by the patient was extreme sensitivity of the posterior teeth, especially with drinks and cold food. The patient was subjected to clinical and radiographic examinations and received orientation for oral hygiene and treatment of sensitivity with fluoride.

During anamnesis, his mother did not know if anyone else in the family had the same problem and reported that the son was diagnosed with attention-deficit hyperactivity disorder. An intraoral examination revealed teeth with alterations in size and shape, yellow-brown discoloration (Fig. 1) and covered by rough enamel. Clinical examination revealed the presence of generalized bacterial plaque on the surface of the teeth. A complete periapical radiographic

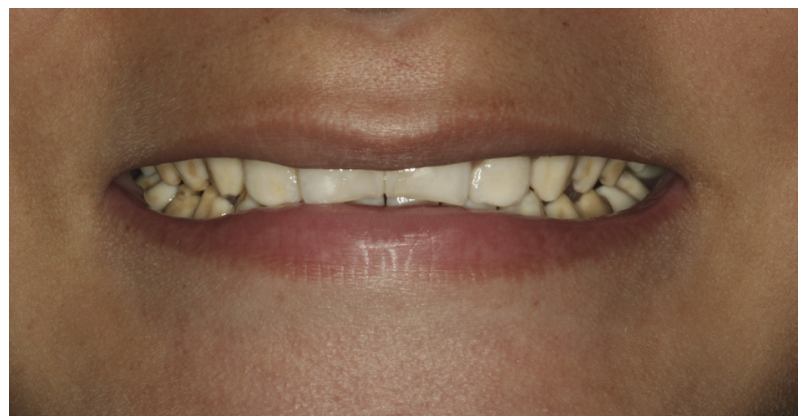

Figure 1. Initial aspect of the teeth. 
examination was ordered, which revealed absence of enamel in some places. Study models were made to complement the clinical examination.

For the anterior teeth, was planned a future rehabilitation with direct veneers using composite resin for aesthetic recovery. Desensitization was not recommended because the patient did not report pain in the region. However, in the posterior teeth, the patient reported pain when ingesting cold or citrus foods and sensitivity level 8 on the visual analogue scale to classify tooth sensitivity asmild, moderate or severe, after application of an air jet at a distance of $10 \mathrm{~cm}$, for about $2 \mathrm{~s}$. Thus, immediate desensitization using self-etching adhesives was proposed.

In the preventive and early stages were performed dental prophylaxis, removal of dental calculus, topical fluoride application, oral hygiene instruction and sealing of the posterior teeth with adhesive. Desensitization using the Single Bond Universal self-etch adhesive system (3M ESPE, St. Paul, MN, USA) was performed after careful prophylaxis with pumice and water, followed by relative isolation of the regions that would be subjected to the clinical protocol. At the buccal, lingual or palatal and occlusal faces (Figs. 2A and 2B) of all the posterior teeth, $\overrightarrow{5}$ the adhesive system was applied in two layers. The first was actively applied with a microbrush for $20 \mathrm{~s}$, without curing. The second was applied in a passive way, waiting
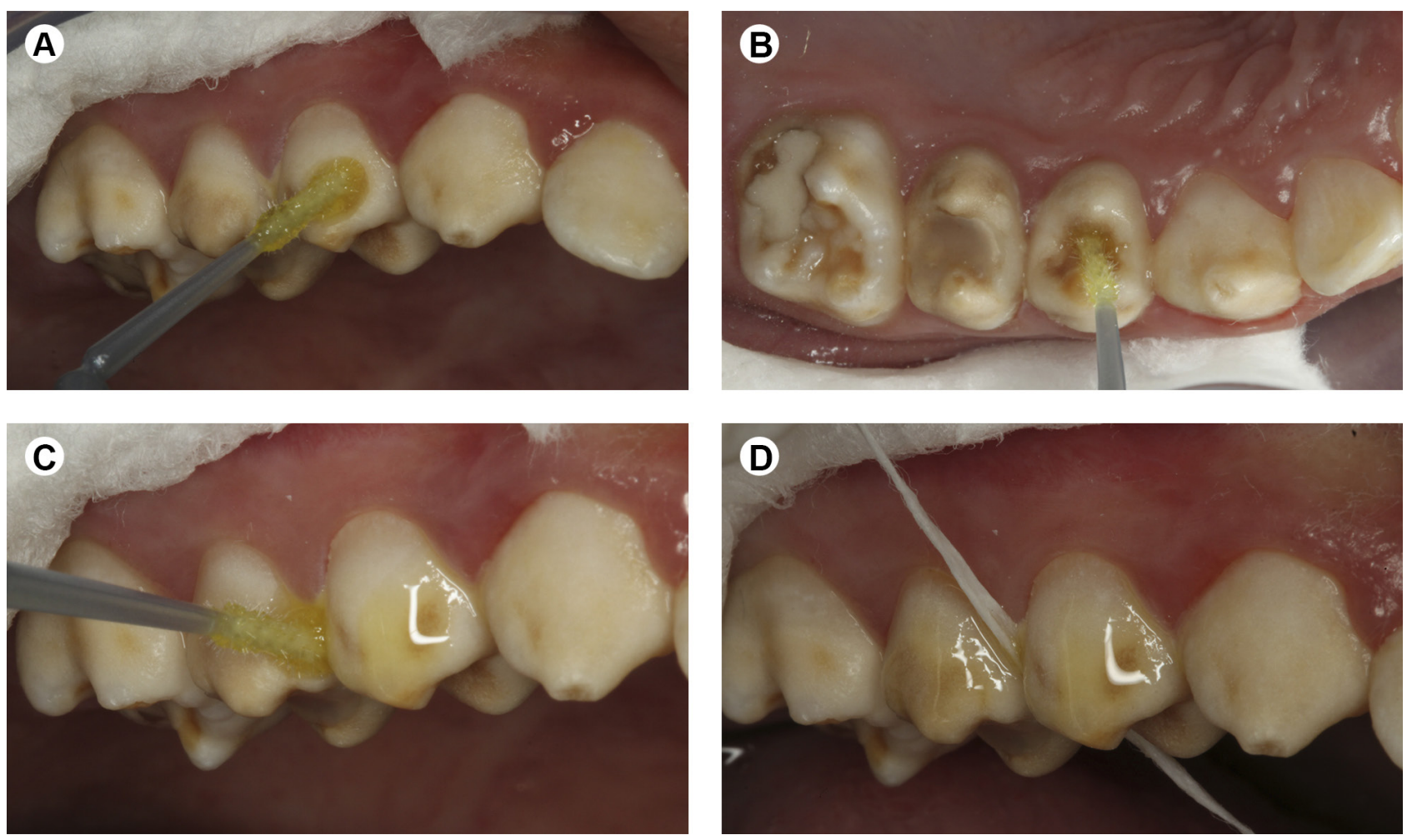

Figure 2. Application of the adhesive system on the buccal (A), occlusal (B) and proximal (C,D) surfaces. 
dimension, enamel deficiencies, failed tooth eruption, impaction of permanent teeth, aesthetic commitment and anterior open bite $(1,2,15)$. The treatment of these cases is related to many factors, including age, damage severity, aesthetics, socioeconomic status, psychosocial aspects, and functional and social demands $(14,16,17)$.

The literature presents different treatments that use all types of glass ionomer cements, stainless steel crowns, amalgam restorations, adhesive restorations, metal-ceramic crowns, prefabricated resin veneer, and multiple extractions requiring an overdenture $(7,11-14)$. The main treatment goals are to preserve maximum tooth structure, restore masticatory functions and aesthetics, and eliminate tooth sensitivity $(7,13,17)$. Dashash et al. $(11)$, in a Cochranebased review, evaluated the success rates (aesthetics, masticatory function and longevity of restoration) of different interventions. However, the authors of this systematic review failed to identify the best intervention. Thus, without a high-quality evidence, the authors planned the treatment in stages according to priority. Normally, the dentist should first reduce or eliminate tooth sensitivity, improve aesthetics and provide oral hygiene orientation. The dentist should then eliminate the loss of vertical dimension and finally complete the rehabilitation $(7,12-14,17)$.

Fluoride is important to Al patients because of their high risk of caries and it may reduce a little bit the hypersensitivity and improve this effect when associated with the occlusion of the dentin tubules (18). Bonding agents are used to obliterate dentin tubules by reducing or eliminating tooth sensitivity $(11,14)$. The present study showed elimination of this problem by the Single Bond Universal adhesive (3M ESPE). Another positive effect of the protocol was the improvement of the patient's oral care because he no longer felt pain during tooth brushing.

The bond strength in dentin $\mathrm{Al}$ is significantly lower than that in normal dentin because of the hypermineralized sclerotic tissues. These sclerotic areas are probably more resistant to demineralization by acid etching, impairment or prevention of resin infiltration. Extending the etching time showed no significant difference and the hypermineralized layer was dissolved by acid. However, over-etching of the underlying mineralized dentin may occur; thus, resin monomers would not penetrate the full depth of the demineralized dentin, producing a porous, non-resinous, infiltrated zone (19). The universal adhesives showed equivalent bonding quality to that of dentin regardless of etching mode (20). In Al enamel, this adhesive system without previous etching provided a bond strength similar to that of etch-and-rinse adhesive systems (21).

The choice of this protocol was based on sensitivity control and reduced clinical time, because the patient had attention-deficit hyperactivity disorder and had no loss of vertical dimension. The use of a universal adhesive eliminated the etch, rinse and dry phases, and showed relevant results in terms of bond strength $(20,21)$, thereby obliterating the dentin tubules, and reducing or eliminating tooth sensitivity $(11,14)$. Thus, based on the present clinical case, it may be concluded that the sealing of the exposed dentin on teeth affected by Al by a universal self-etch adhesive system effectively reduced or eliminated tooth sensitivity immediately and maintained this effect during the 12-month follow-up period. Further clinical studies are required, but the technique seems promising, as it greatly improved the patient's quality of life. It had an immediate effect, was effective and was a simple clinical option.

\section{Resumo}

0 objetivo deste estudo foi descrever uma técnica de dessensibilização dental imediata, usando o adesivo universal em paciente adolescente diagnosticado com amelogênese imperfeita. 0 paciente afetado pela amelogênese imperfeita apresentava dentes extremamente sensiveis, e foi submetido a aplicações de adesivo universal para dessensibilizar os dentes afetados por amelogênese imperfeita. A redução da sensibilidade dentária foi avaliada pela escala analógica visual durante todas as reavaliações. A técnica foi efetiva na redução da sensibilidade dental. Concluiu-se que o uso do sistema adesivo foi eficaz na imediata dessensibilidazação dentária e mantida após doze meses de avaliação.

\section{References}

1. Aldred MJ, Savarirayan R, Crawford PJ. Amelogenesis imperfecta: a classification and catalogue for the 21st century. Oral Dis 2003;9:1923.

2. Ayers KM, Drummond BK, Harding WJ, Salis SG, Liston PN. Amelogenesis imperfecta: multidisciplinary management from eruption to adulthood. Review and case report. N Z Dent J 2004;100:101-104.

3. Stepanopoulos G, Garefalaki ME, Lyroudia K. Genes and related proteins involved in amelogenesis imperfecta. J Dent Res 2005;84:1117-1126.

4. Pithan JC, Malmann A, Pitan SA, Costa CC. Amelogênese Imperfeita: revisão de literatura e relato de caso clínico. Revista ABO Nacional 2002;10:88-92.

5. Melo T, Beltrão M, Spohr A. Amelogenese Imperfeita - relato de caso. J Appl Oral Sci 2005;13:212-217.

6. Ergun G, Kaya M, Egilmez F, Cekic-Nagas I. Functional and esthetic rehabilitation of a patient with amelogenesis imperfecta. J Can Dent Assoc 2013;79:d38.

7. Sreedevi S, Sanjeev R, Efraim R, Joseph M. Interdisciplinary full rehabilitation of a patient with amelogenesis imperfecta: a case report with 8 years follow-up. J Int Oral Health 2014;6:90-93.

8. Sengun $A$, Ozer F. Restoring function and esthetics in a patient with amelogenesis imperfecta: a case report. Quintessence Int 2002;33:199204.

9. Poulsen S, Gjorup H, Haubek D, Haukali G, Hintze H, Løvschall H, et al.. Amelogenesis imperfecta: a systematic literature review of associated dental oro-facial abnormalities and their impact on patients. Acta Odontol Scand 2008;66:193-199.

10. Parekh S, Almehateb M, Cunningham SJ. How do children with amelogenesis imperfecta feel about their teeth? Int J Paediatr Dent 2014;24:326-335.

11. Dashash $M$, Yeung CA, Jamous I, Blinkhorn. Interventions for the restorative care of amelogenesis imperfecta in children and adolescents. Cochrane Database Syst Rev 2013;6:CD007157.

12. de Sousa JF, Fragelli CM, Paschoal MA, Campos EA, Cunha LF, Losso EM, et al.. Noninvasive and multidisciplinary approach to the functional and esthetic rehabilitation of amelogenesis imperfecta: a pediatric 
case report. Case Rep Dent 2014;2014:127175.

13. İzgi $A D$, Kale $E$, Niğiz R. Amelogenesis imperfecta: rehabilitation and brainstorming on the treatment outcome after the first year. Case Rep Dent 2015;2015:579169.

14. Marquezin MC, Zancopé BR, Pacheco LF, Gavião MB, Pascon FM. Aesthetic and functional rehabilitation of the primary dentition affected by amelogenesis imperfecta. Case Rep Dent 2015;2015:790890.

15. Alachioti XSA, Dimopoulo E, Vlasakidou A, Athanasiou AE. Amelogenesis imperfecta and anterior open bite: etiological, classification, clinical and management interrelationships. J Orthod Sci 2014;3:1-6.

16. Chaudhary $M$, Dixit $S$, Singh $A$, Kunte $S$. Amelogenesis imperfecta: report of a case and review of literature. J Oral Maxillofac Pathol 2009;13:70-77.

17. Mete JJ, Dange SP, Khalikar AN, Vaidya SP. Functional and esthetic rehabilitation of mutilated dentition associated with amelogenesis imperfecta. J Indian Prosthodont Soc 2012;12:94-100.
18. Petersson LG. The role of fluoride in the preventive management of dentin hypersensitivity and root caries. Clin Oral Invest 2013;17:S63-S71.

19. Hiraishi N, Yiu CK, King NM. Effect of acid etching time on bond strength of an etch-and-rinse adhesive to primary tooth dentine affected by amelogenesis imperfecta. Int J Paediatr Dent 2008;18:224230.

20. Takamizawa T, Barkmeier WW, Tsujimoto A, Berry TP, Watanabe $H$, Erickson $\mathrm{RL}$, et al.. Influence of different etching mode on bond strength and fatigue strength to dentin using universal adhesive systems. Dent Mater 2016;32:e9-e21.

21. Yaman BC, Ozer F, Cabukusta CS, Erem MM, Koray F, Blatz MB. Microtensile bond strength to enamel affected by hypoplastic amelogenesis imperfecta. J Adhes Dent 2014;16:7-14.

Received December 11, 2015 Accepted April 25, 2016 